\title{
Precarious housing in the Salvokop neighbourhood: A challenge to churches in the inner City of Tshwane
}

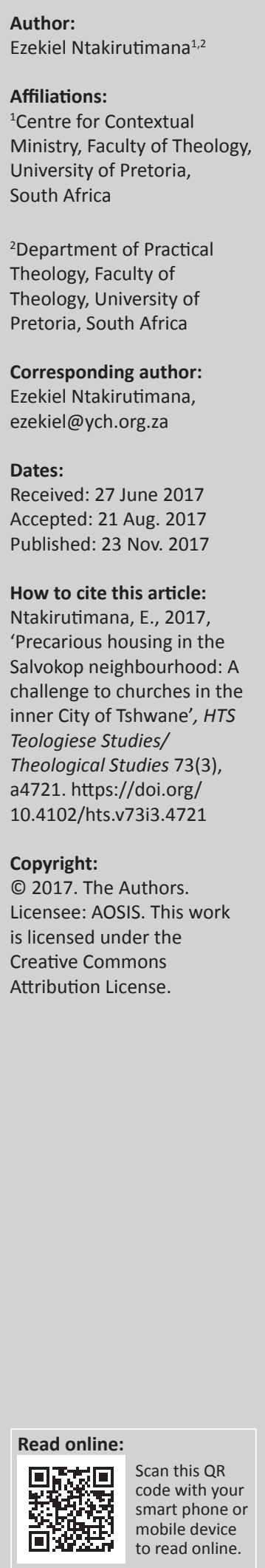

This article describes the daunting challenge of precarious housing in Salvokop located in the southern part of inner City of Tshwane, Gauteng Province. Insecure tenure, unmaintained dwellings, overcrowding, mushrooming of backyard shacks and the rise of the informal settlement, all that led to deep levels of vulnerability and neighbourhood deterioration. Current conditions show that life in that neighbourhood is fraught as substandard housing degenerated into slum and squalor. This concern emerged among other salient pressing issues of poverty and vulnerability from the World Café and Focus Groups with the inner city churches including those from Salvokop. The article set out to describe precarious housing, unpleasant living conditions owing to the fact that human beings stay in unsuitable dwellings while the environment deteriorates. Taking into account their circumstances, the article's aim was to recapture the extent to which the residents suffer as a result of living in dwellings unfit for human habitation, rethinking an alternative model to respond. A theological agenda for future ecclesiological engagement was discerned forthwith recommendations. The article makes a contribution towards the theology of the city in that it stimulates church practices and housing of poor people in Tshwane. It does so by engaging in a unique way grassroots knowledge from the different inner city congregations. This process used the platform of surveys, World Café style gatherings and Focus Groups. In conversation with the primary source, this article also contributed with original data generated with the Salvokop residents whose stories helped to expend on horizons of housing, which is acknowledged. All the inner city church contributors of the realisation of the study objectives are also recognised.

\section{Introduction}

The opening page of the classic book, Getting to the 21st Century: Voluntary Action and Global Agenda written by Korten (1990), reflects a startling thesis statement, 'we have a problem ...' The author made this claim after studying a global phenomenon of 'poverty' as associated with a lack of strategies to tackle from its very underlying causal roots. Thus, adoption of the expression 'we have a problem' lies behind the article's efforts to find a language that better articulates the real-life experience that the residents of the Salvokop neighbourhood face as a result of precarious housing. This situation has largely dominated among other social issues debated during the World Café and Focus Group meetings with the inner city churches, including those operating in the neighbourhood. While expressing the enormity of this problem, a concern was raised that the involvement of the inner city churches is rather superficial as they only focus on outreaches, door-to-door evangelism, prayer cells, counselling sessions and praying for the sick. Besides direct involvement of the inner city churches, People Upliftment Programme (POPUP) is a ministry of Doxa Deo Church which is based in the neighbourhood. Its programmes are also short-term and are intended to address primary healthcare, soup kitchen service, food parcels and clothing distributions. Tshwane Leadership Foundation (TLF) is also another church-based organisation that spins a number of projects in the neighbourhood. They focus on early child development programmes, homework centres, community forum, outreaches and a multipurpose community centre facility. Yeast City Housing (YCH), an independent legal entity established by TLF is also present in the neighbourhood and has made an attempt to improve housing availability. Its housing model is recommended in the subsection Rethinking, an alternative model to facilitate change.

Note: This article forms part of a collaborative research project entitled 'Religious innovation and competition amidst urban social change: a Pretoria case study'. The project was funded by the Templeton Foundation as part of an African-wide enquiry on 'Christianity and social change in contemporary Africa'.

The project is also a sub-theme of the 'Faith in the City' research project, hosted by the Centre for Contextual Ministry in the Faculty of Theology, University of Pretoria. 
In view of all these specified programmes, the problem statement of the study is that precarious housing is a matter of growing concern for the residents of the Salvokop neighbourhood. Three aspects that help to create a bigger picture of this problem are descriptive to show the extent to which the residents are deeply affected. First of all, the residents stay in free-standing houses inherited from the colonial and apartheid era. However, the viability of these ventures has gradually dropped because of a lack of maintenance and upgrades of basic service infrastructures in the neighbourhood. Secondly, there is a question of overcrowding in these houses mainly because of illegal subletting. The residents tend to accommodate desperate poor people who cannot afford rent elsewhere in the inner city. This situation has gone beyond proportion because it is apparent that the Department of Public Works, the landlord, has lost managerial control, which has led to chaos. Thirdly, an increase of backyard shacks and occupation of open land in the Bagdad informal settlements is remarkably noted to describe precarious housing. Poor people are erecting unsafe structures in an open space, which does not have basic facilities including water, electricity and sanitation.

Accordingly, these factors and others show clearly that precariousness of housing in Salvokop is a matter of greater concern. The study notes that since the Department of Public Works took over the administration from Transnet, the housing situation in the neighbourhood remains uncertain. This study is intended to describe the problem and to discern an alternative theological agenda for future ecclesiological contributions towards a change. Gloeck (2011:14), De Beer (2016) and Batho Earth (2016) help review a historical background of the initial establishment of Salvokop to determine factors that have influenced housing delivery in the past years and how poor people were socially affected. These factors are related to unfair policies and patterns of the colonial and apartheid rules, which promoted social exclusion. De Beer (2014a) and Mbanjwa (2012) offer an overview of the contemporary Salvokop precinct in terms of 'a site of struggle' because of its current critical human condition. Referring to past experiences, there is perception which creates fear that 'very soon Salvokop site could very well be redeveloped at the expense of the poor who lived there for the past 20 years ...'

In the view of these reports, the experience of precarious housing implies 'inadequate housing' and is linked to poverty and human vulnerability as a result of resource deprivation and social exclusion (Doyle \& Williams 2016:3). Taking all these circumstances into account, the study agrees with the United Nations (2015:1) to affirm '... recognition of the inherent dignity and of the equal and inalienable rights of all members of the human family is the foundation of freedom, justice and peace in the world ...'. The study also embraces the vision of the Habitat for Humanity South Africa (2016:2), which advocates for 'a world where everyone has a decent home'. It is within this pressing social context that the study sets out to analyse the implications of precarious housing in the neighbourhood of Salvokop focussing on the four main conversations as follows:

- The first conversation is dedicated to an over focusing view of how Salvokop started in the years back, what has socially changed and how housing service was administered.

- The second conversation connects with historical overview to recapture an urban perspective of the contemporary Salvokop assessing mechanisms behind precariousness of housing in the neighbourhood and extent to which the residents are affected.

- The third conversation redirects its focus on rethinking an alternative model to respond towards precarious housing.

- The fourth and last conversation discerns an alternative theological agenda for future urban ecclesiological involvement in response towards precarious housing in Salvokop.

\section{Clarifying the study focus and objectives}

In alignment with the title of the article, the study is conducted under the broader context of human rights deprivation, which propels poor people to urban social margins where they face a deplorable life without social service net. Specifically, it deals with a struggle for poor people to access proper housing in the inner city. The envisaged objectives are stated as follows:

- to recapture the historical background of the Salvokop neighbourhood to establish obstacles and social patterns that hampered housing for poor people

- to reassess the current state of the neighbourhood to get a bigger picture of the precarious housing problem while exploring the extent to which the poor people are affected

- to demonstrate the active role all the residents of Salvokop should play to participate in finding a solution towards a precarious housing problem

- to discern an urban alternative theological agenda for future considerations as; both the residents and the churches journey together to address precarious housing.

\section{Clarifying the methodology}

To achieve the objectives of the study, the methodology adopted a multi-level and interdisciplinary framework, which helps to conduct an inquiry into issues of urban spatial justice in the pressing social context of poor people who live in dwellings that are unfit for human habitation. This methodology is specifically shaped by an urban philosophical praxis, which harnesses grassroots knowledge from the fieldwork. This recognises that research is:

not only exploring conceptual or theoretical frameworks, but based on actual challenges and questions articulated by local participants and stakeholders, shared action, reflection, dialogue and research are engaged in for real-life solutions and innovations. (Bergman 2005 and Pohl \& Hirsch Hadorn 2006, sited in De Beer 2014a)

Accordingly, the aspects of the study methodology are structured as follows:

- Literature review was an important aspect of the methodological framework used to achieve the objectives of the study. 
- Aside the literature review, the World Café style gatherings and Focus Group sessions with inner city churches have been used to gain empirical knowledge. From the side of Salvokop, four churches were invited to participate in the Focus Group meetings. However, only two churches availed themselves for the meetings which was a disappointing part in the study. Focus Group sessions were conducted on 25 September 2016, 03 May 2017 and 14 May 2017.

- Another component of the methodological framework of the study has been individual interviews with ten residents from Salvokop to get their view on how precarious housing affects them and what role the residents can play in the housing process. The interviews took place on 28, 29 and 30 April 2017.

- Again, the study has relied on my personal observations from pastoral experience as a minister who is running a church in Salvokop. The regular door-to-door outreach we do in this area has exposed me to real-life experiences poor people face on a daily basis as a result of staying in substandard houses. My involvement with $\mathrm{YCH}$ is also another experience that made me aware of the appalling situation of housing in the neighbourhood. As indicated in the introduction, $\mathrm{YCH}$ has recently built an affordable housing project in the area. This project stimulated me to see Salvokop precinct with more potential to improve the living conditions of all the residents through proper housing suited to their various social and economic circumstances.

In short, these above important aspects of the methodological framework have been the guiding principle in the study to investigate the precarious housing problem in the Salvokop neighbourhood and how the residents are affected because of a lack of interventions.

\section{Four conversations characterising the study}

Keeping in mind the title of the article, there are four main conversations that lead the study: (1) an urban historical perspective of Salvokop in relation to housing situations, (2) presentation of the contemporary Salvokop and precarious housing, (3) rethinking an alternative model for both the residents and the inner city churches journeying together to respond towards the problem of precarious housing and (4) discerning an alternative theological agenda and recommendations for future ecclesiological involvement.

\section{Presenting an urban historical perspective of the Salvokop neighbourhood}

An epistemological inquiry set forth in this first conversation describes historical settings that characterise Salvokop, a site regarded as one of the biggest and growing informal settlements in the inner City of Tshwane. The reader is informed that a teleological position pursued through this process is not one of generating a scientific spatial configuration to scrutinise architectural details as underpinned by Naude (2014:14). The study rather takes a different angle of social experience in relation to 'right to a space' and access to proper housing in city. Massey and Thrift (2000) express that vision quite strongly, saying that access to the city should be understood as a matter of:

the rights of being, becoming, and interconnecting in the city, rights that do not flow alone from the ways in which the physical space is organized, but also from the development and expressive opportunities given to [poor and vulnerable] people ... (p. 45)

Davey (2001) echoes the same sentiments, analysing dramatic experience of social and economic exclusion owing to the powers that compete for control of the city at the expense of poor people. He speaks out against these practices stating that:

Civilisation we seek in the new Millennium is about how an urban people learn to live and organize together, and handle that attribute of urban living that provokes change, creativity and experiment- in patterns of social life, politics and economics as well as the arts of sciences ... (p. 21)

All these above insights give a good perspective, helping to assess historical background of Salvokop starting from its inception. Records from history, however, show that its establishment reflects worse experience of racial segregation from the South African history of colonial and apartheid powers. Gloeck (2011:11) is among the researchers who document key events leading to the epithet of social exclusion and violation of human dignity. His report reveals that the Salvokop site started years back dated to the period of the First Anglo-Boer War in 1880. This time the site was known as Time Ball Hill, which served as a central point of the mail delivery in the city. Towards 1886, after the discovery of the main gold reef on the Witwatersrand, Gloeck continues his study noting that enough funds became available to start businesses and this is when the site was considered to host important projects. It was Nederlandsche Zuid-Afrikaansche Spoorweg-Maatschappij (NZASM), a Dutch company that was chosen as a reputable engine to champion the railway line in 1892-1898 and the NZASM Village vision or Salvokop Village emerged in this process. Artefacts (n.d.) documents other businesses that were initiated comprising central workshops for cannon maintenance, ammunition productions, shooting galleries and recreational space. This report reveals that in 1902, after the Anglo-Boer War conflict, NZASM changed into the Central South African Railways and then South African Railways and Harbours. This led to a junction of Cap Government Railways, Natal Government Railways and Central South Africa Railways. Transnet comes from that background and today its general operations have been consolidated into Spoornet and the South African Commuter Corporation. It is believed that all the above business activities became substantially a major link and booster to the national economy. Astrup (2005) gives an account of the economic situation as follows:

The NZASM railway initiatives, which focussed on the hub of Salvokop before 1902 (IMR/SCAR), was the biggest single state driven infrastructure venture the Transvaal Republic ever 
undertook. The venture provided job opportunities for thousands of white and black citizens at the time, and made a huge contribution to the ZAR economy, in terms of revenue and of sustaining the all-important mining industry and also the agricultural community. (p. 17)

This above assessment leads now to the political and social life discussion. Records show that as economy continued to grow, it was between 1890 and 1930 when a need arose to provide housing to the railway line employees to live closer to work. However, reports confirm that the framework applied that time to address the need, was based on the colonial and apartheid policies. Housing service undertaken only favoured the workers from the white community excluding their black counterparts. As Wenhold (2008:63) and Gloeck (2011:15-16) reveal, such exclusion carried on until the general elections of 1948 when the policy of racial segregation, known later as, apartheid, openly came into force. The implementation of this policy had its own dramatic impact, including forced removals of all the non-white residents from the Salvokop site and most of them were pushed to the Mamelodi Township approximately $20 \mathrm{~km}$ away from the city. It was only in 1990 after President F.W. de Klerk became State President and after negotiations to end the apartheid regime that black workers began their journey back to Salvokop. More poor people continued to move to the area with an intention to start businesses and to look for accommodation (Gloeck 2011:16). Of recent development, it is observed that Salvokop precinct has been integrated into the government plan of remaking South Africa's Capital City, taking into account various factors:

The concepts of liveability, resilience and inclusivity are anchor principles that will guide how the City sets policy and investment priorities as well as balance competing needs of social, spatial, and environmental issues brought about by the City's everchanging population dynamics. Furthermore, these principles seek to bring about the realisation of the City's new urbanism and smart city aspirations. This vision serves as development logic for the four decades of game changing and it is a collective call to all stakeholders and residents. (Tshwane Vision 55 2013:34)

From operational ground, however, the Vision 55 does not match reality. In his report, Mudzuli (2014) makes reference to some of the major government projects in Salvokop such as the Freedom Park, Gautrain and the Statistics SA Head Offices. Although these projects are intended to contribute towards the city renewal, an important social component is missing to integrate poor people in the urban development plan. De Beer (2014b) challenges the government for continuing to turn a blind eye to the suffering of the Salvokop residents who live in 174 inadequate houses while scenarios of backyard shacks and informal settlements continue to multiply in the neighbourhood. These issues are reflected in the next conversation on the contemporary Salvokop. In summary, historical records show that Salvokop is emerging from the background characterised by unjust policies that promoted social exclusion in general. It is crucial to keep this perspective of the past in mind in assessing the current social context in light of the theme of this study.

\section{Analysing precarious housing in the contemporary Salvokop neighbourhood}

Now that a historical background of Salvokop has been covered, this present conversation opens a new debate about its current social conditions. Officially, the neighbourhood falls directly under the administration of the Department of Public Works whose responsibility is to ensure that space is well managed to promote proper human settlement in line with the Tshwane Vision 55 mentioned previously. Looking at the present situation, however, the residents are faced with dire precarious housing and this challenge emerged from the Focus Group meetings with the inner city church including those running in the neighbourhood. These Focus Groups form part of the World Café gatherings, which have already been mentioned earlier (see Introduction Clarifying the methodology) as an initiative championed by the Centre for Contextual Ministry from the Faculty of Theology, University of Pretoria. Their main purpose was to establish how religious innovation and competition deal with urban vulnerability and change in specifically identified communities in Pretoria. The targeted areas in this process include the inner city of Tshwane and Mamelodi East, a section closer to the Woodlane Village, which is generally known as one of the wealthiest suburbs of Pretoria. Salvokop that this study focuses on was selected as part of the inner city to engage all the inner city churches on urban social issues and the role played to respond to those challenges.

Firstly, the Focus Group participants made reference to various social issues the neighbourhood faces and included on their list precarious housing. They referred to the degradation in housing established several years, dated to the period of colonialism and apartheid regime, as I also profiled this in the previous conversation. These houses have not been maintained and their current state shows that they are no longer fit for human habitation. The participants stated that after the Department of Public Works took over the administration from Transnet, there was hope that the situation would change, instead the neighbourhood is gradually deteriorating. The identified problems include lack of maintenance and upgrade of basic infrastructures such as sewer systems, electricity, water and sanitation. Looking at the reports by Batho Earth (2016:32) and Salvokop Development Forum (2017), the neighbourhood is socially becoming disintegrated as criminals tend to take advantage of the situation to carry out their illegal activities, that is, theft, vandalism, substance abuse and illegal taverns, which attract the underage and sexual violence.

Secondly, besides the unmaintained houses and the collapse of basic services, the Focus Group participants also identified overcrowding in these houses mostly because of illegal subletting. It is believed that poor people move to Salvokop to look for cheaper places to rent because flats are expensive in the city. De Beer (2014b) confirms that there are already 3000 families living there. In assessing implications and problems lying ahead, Batho Earth (2016) states as follows: 
An extensive influx of jobseekers to the Salvokop area could result in negative social impacts such as the extension of the Baghdad informal settlements with associated environmental pollution, an increase in the number of backyard shacks within the formal residential component of Salvokop, social conflict between the jobseekers and locals to secure employment, conflict between informal vendors (also seen as jobseekers) for new business, misbehaviour of jobseekers (e.g. possible increase in alcohol use) possible increase in crime due to these jobseekers being unemployed, as well as increased pressure on already strained infrastructure and additional pressure on health and community services. (p. 37)

In view of influx and overcrowding, poor people tend to exploit each other through the situation of subletting. Batho Earth (2016:23) explains the practice saying that, 'for some of the formal tenants who are unemployed, subletting is a comfortable source of income'. During the interview with one of the Salvokop residents, it was revealed that a backyard shack or a room in the house can be rented out for a large amount of between R1000 and R1200 monthly. It was also noted that a single yard can accommodate up to 23 shacks (interview May 2017). In comparison, this rent is high looking at Inkululeko Centre where YCH charges R750 per $30 \mathrm{~m}^{2}$ unit size for a family earning a monthly income between R1500 and R3500 (Yeast City Housing Pamphlet 2016 \& Batho Earth 2016:24). This example shows that if a similar model can be replicated with more housing options to accommodate even those with lower income, it is possible to eradicate overcrowding and shacks in Salvokop.

Thirdly, an increase of shacks in open land besides backyards has been noted as another indication of precarious housing. These shacks are built with card boxes, whereas others are built with plastic sheeting, which poses a very high health and safety risk because paraffin is used to prepare food. Reference was here made to Baghdad ${ }^{1}$ informal settlement mentioned in the early discussions. Batho Earth (2016:23) estimates that there are currently 250 shacks in Bagdad and that each shack can accommodate up to 10 individuals. Among the poor and vulnerable people residing in these shacks include women and children who live without water, electricity and sanitation. This is how one resident tells a story of her life:

‘We have to go to ask water from POPUP and sometimes we do not get it because they say water is now expensive. Can you imagine spending a week without taking bath ...? We do not have privacy, we do not have toilet, there is no electricity to cook food, and life is difficult here.' (Interview 2017)

One participant from the Focus Group meetings blamed the churches for not doing much to help:

'this place is like Sodom and Gomorrah. You will find some smoking weed [drugs] or prostituting. They get here and it's not a fun place for them ... when you go to the people and you tell them about Jesus they will tell you that right now at that moment Avenue. what Jesus can do for them because their children are hungry and they don't have anything to feed them.' (Focus Group)

Most of the local churches from Salvokop are operating informally (Batho Earth 2016:22). Some of them are operating in shacks, and others have hired space from Jopie Fourie Primary School, whereas some others are hosted in the TLF Community Centre facility including the Free Methodist Church that I am running in the area. As it was mentioned in Focus Group meetings, some of these churches are involved in community outreaches and counselling. Other churches help with food parcels and clothing to needy people. However, Focus Group participants pointed out that although such support is important, it does not help to address the problem of poor people who live in unsafe structures without basic facilities.

An important element from the report by Batho Earth (2016:23) is that the Bagdad shack dwellers should not just be viewed as the recipients of handouts because some of them have potential of all kinds of skills and experience The report mentions general construction-related skills, for example, plastering, tiling, painting, brick laying, welding, mechanics, plumbing, electricians, agriculture-related skills and so forth. One of the ways the churches can help is to link these residents with employment agencies or construction companies for job opportunities. Others can be empowered to start small businesses of income generation to sustain themselves and their dependants. Kretzmann and McKnight (1993:1-5) promote this model though Asset Based Community Development approach in their understanding that, development is about 'capacity-driven' and 'participatory' practices rather than a 'deficiency-driven' practice.

In brief, one big challenge in Salvokop, given its historical background of unjust policies, is to cultivate changes that promote the value of neighbourhood through social integration prioritising access to adequate housing so that the poor people can live closer to economic opportunities in the city.

\section{Rethinking an alternative model to facilitate change}

On the basis of precariousness of housing as faced by the residents of Salvokop, this conversation explores an alternative model for the churches to respond in a more practical way. This model is assessed through the lens of social justice, a vision which fascinates Jackson (2005:356) who advocates for 'equal redistribution of resources among individuals with competing needs'. The vision also inspires Bankston III (2010:165) who states that economic resources 'redistribution is not as a matter of compassion or national interest, but as a matter of the rights of the relatively disadvantaged to make claims on the rest of the society'. This interpretation is about advocacy of human rights, which Kritzinger (2012:235) promotes by calling on the churches to 
be the mouthpiece of voiceless people in community. He believes that it would theologically be irresponsible to say that it is not in their business to address political or economic matters with a wrong motive that they are only 'called to be spiritual and must thus work on religious issues in a religious way'.

Applying the above insights in the context of Salvokop, the inner city churches working together with the residents can significantly achieve more in the areas of advocacy and policy lobbying. A unique contribution that the churches can make is, for instance, to prioritise consciousness-raising and awareness of citizens' rights including access to quality housing as enshrined in the Constitution of the Republic of South Africa (RSA 1996:12), Chapter 2 of the Bill of Rights (26). It does not, however, help to advocate for 'appropriate housing for everyone' without being aware of policy constraints. Pathways out of homelessness (2015:33) promotes a more inclusive model, which is broad and open to house homeless families. ${ }^{2}$ Gaines and Armstrong (2011:81) advocate for the same model in their understanding that each citizen, including those who have been labelled as 'unhousable', should access proper housing to live with dignity. It is therefore believed that pathways out of precarious housing require an inclusive policy that embraces African value of $u b u n t u^{3}$ to house the most vulnerable people in society, that is, refugees, asylum seekers and other vulnerable citizens with dire social needs. The role of the churches in this undertaking should then go beyond outreach and handout programmes to a more long-lasting solution.

Lessons learnt from the early Methodists do not, however, suggest that churches' relief initiatives should stop as such decision would be undermining the integrity of Jesus' Parable of the Good Samaritan (Lk 10:25-37). The Methodists integrated well relief projects with empowerment of poor people in various ways in their view that, 'the temporary aids, given to subdue prejudice and support the weak, shall, like scaffolding, be removed ...' and that means to achieve fuller life (Wesley 1827:270). In their practices, Methodists were creative and innovative to an extent of recycling old buildings for housing purposes as reflected in the model that follows:

This ruined building at Windmill Hill, Moorfields, the building was wrecked by an explosion, and was left derelict for more than twenty years. At a cost of $£ 800$, Wesley made this his headquarters. Out of 'a vast uncouth heap of ruins' Wesley made a chapel which would accommodate some fifteen hundred people. There was a Band Room behind the chapel holding about three hundred people; at north end a school, and at the south end the Book Room. Over the Band Room were apartments for Mr. Wesley, assistant preachers; a coach house and stable stood in an

2.According to the current Social Housing Act 16 of 2008 , for poor people to participate in the affordable housing programme, a monthly combined family
income between R1500 and R15000 is required. More additional qualifying criteria include a requirement for households to be of South African citizenship or to hold permanent resident permits for immigrants in the Republic.

3.African common value of ubuntu that promotes human dignity and cultural diversity is described in Hankela (2014:13): '... people exist in a web of relationships ... if one person's dignity is violated ... all people are also affected.' open yard to the north, while at the south side was walled-in garden in which were 'some forest trees. (Boyling n.d.:5-6)

This example represents a model of good practice showing how urban space can be innovatively used to improve lives of citizens through housing. Basset (2013:2) and Kruythoff (2003:204) support this idea saying that spatial justice implies:

to improve the livability and safety, to promote a sustainable development, to improve the quality of working and living, to strengthen the economic base, to enhance the social cohesion, to improve accessibility, to upgrade the quality of public space ...

Integrity flowing from the phrases, '... to improve accessibility ...' '... social cohesion ...' and '... urban public space ...' reminds me of a conference I attended in Pretoria CBD where a speaker claimed that poor people who occupy urban space illegally, like in Bagdad, are in a matter of fact 'affirming life' (notes from the Conference paper 2017). Such utterance is politically provoking as it is illegal for people to erect shacks in the municipal demarcated land without permission, resulting in evictions without alternative housing. I concur with the speaker suggesting that shack dwellers should not just be ill-treated as illegal subjects in space of their last resort in the city. Marchant (2004:10) is inviting the church to respond because 'mission in the complexity and tangle of the urban will bring us again and again to the cross and resurrection'. Theologically, the cross is touchstone for the church to be in solidarity with poor people in fighting for liberation. It is also bearing in mind that lack of proper housing steals away human dignity and that it takes commitment and self-sacrificing love for the church to participate in this struggle. The courageous spirit of tenacity and resilience is a life lesson learned from Abahlali base Mjondolo [shack dwellers] from Durban who are able to mobilise themselves to resist injustice as follows:

shack dwellers should organize themselves and think and speak for themselves, ... shack dwellers should no longer be 'ladders' for the politically ambitious but should fully own their own politics and own it in common. The central idea in the understanding of a living politics is that politics should not be something imposed on people from above, via sterile and often alienating dogma but should rather be something that, in its discourse and practice, emerges from and speaks to immediate life world of shack dwellers. (Pithouse 2009:262)

Abahlali share the same courage with Social Justice Coalition (SJC) from Khayelitsha, Kraaifontain, Crossroads and Gugulethu in Cape Town. United with one voice, they recently protested against the City Council for unjust budget allocation ignoring to prioritise adequate housing for those living in shacks (SJC 2017). Also, in the City of Tshwane, Tshwane Homelessness Forum of which I am a member, working with partners inter alia the University of Pretoria, University of South Africa and the Department of Social Development, the policy on homelessness was adopted. Subsequently, a summit on homelessness was launched,

4.De Beer 2017, 'Discerning a theological agenda for spatial justice in South Africa' paper presented in a conference on 'Spatial Justice, Reconciliation and Ubuntu', Pretoria, 30 May 2017. 
which resulted in a step further of signing a social contract to addressing homelessness. All these positive results are because of an exemplary model of leadership and advocacy, which emerges from grassroots initiatives determined to promote human dignity.

It is likewise of paramount importance to realise that the residents of Salvokop have a pivotal role to play towards the rebuilding of their neighbourhood. Until they mobilise themselves to defend and reclaim their dignity, their dream of a home in the inner city will remain a thick fog and what is likely to happen is eviction from the city under the pretext of urban planning development. This happened to the shack dwellers who were evicted from Marabastad to Mamelodi as the local government wanted to implement the projects of inner city renewal but the plans did not take place (De Beer 2014b:222). The former residents of Schubart Park and Kruger Park also experienced the same pattern of forced removal. Empty, today 'the buildings stand tall but battered, on the western outskirts of the heart of the capital' (Tlhabye 2016).

It is then argued that both the residents of Salvokop and the churches can journey together in advocating for proper housing in their neighbourhood. An ecclesiological guiding principle flows from Jesus' requirement for the church to become a good shepherd (Jn 10:14) who (1) should know the sheep and (2) who should be prepared to lay life down for them. This call is intended to inspire the church's pastoral care plan to be broader to integrate housing for poor people. Batho Earth (2016:24) showcases a model of Inkululeko Centre project which this study believes may be eye-opening for the churches in the inner City of Tshwane. The project is a new social housing initiative that $\mathrm{YCH}$ completed in Salvokop, as it was mentioned earlier. This housing model can perhaps be reproduced in Baghdad informal settlement to eradicate shacks while contributing to urban regeneration. The Centre was opened in 2014 to house 88 families and the configuration of the units ranges from communal and selfcontained family apartments including lofts. To enhance the comfort of the tenants while meeting affordability target, the house is managed with a new technology. Smart metering system is integrated allowing the tenants to manage well their own utility consumptions in accordance with their budgets. Warm water is supplied into the units through the central heating mechanism heat pump reducing up to $40 \%$ of the total energy consumption if single geysers were installed. Other modern facilities range from the central satellite dish for quality signal of TV and radio, closed circuit television cameras and fingerprint biometrics and the elevator have been put in place (Yeast City Housing Tenant Booklet 2016).

$\mathrm{YCH}$ reputation emerges from its status of a non-profit church-based company and is fully accredited by the Social Housing Regulatory Authority with level one contributor towards B-BBEE ${ }^{5}$ (Yeast City Housing Annual Report 20015). The mandate of $\mathrm{YCH}$ in the inner city is primarily to build and to offer a direct strategic management support service towards affordable rentals for inner city low-income households as prescribed by the relevant legislation. TLF and $\mathrm{YCH}$ continue to share a common vision of building supported homes for people with special needs, that is, people with mental illness, people with terminal illness, girls at risk and women and children in crisis. $\mathrm{YCH}$ further provides communal housing units where facilities are shared to allow very low income earners to access housing. Applying the same model, $\mathrm{YCH}$ provides self-contained apartments ranging from bachelor units to three bedrooms and at the moment, its total financial investments in the city are over R230 000000 (Ntakirutimana 2016:267). Thembelihle Village is the latest project and one of the biggest buildings of its kind in the inner city. The Village was designed to become a mixed-use facility comprising 733 units ranging from residential to retail and space for community development programmes including recycling (Yeast City Housing Tenant Handbook 2016).

In short, an alternative model that helps tackle precarious housing with more impact should invaluably prioritise underlying issues of advocacy and policy lobbying so that the neighbourhood of Salvokop can become a symbol and expression of social justice in the inner City of Tshwane. In the next conversation, it is indicated that the churches should not just see the residents as the illegal shack dwellers who have invaded inner city land aimlessly, but to walk alongside with them in their struggle to achieve a decent housing in their neighbourhood.

\section{Discerning an alternative theological agenda for future ecclesiological involvement}

The penultimate section of the study leads a crucial conversation on an alternative theological agenda for future ecclesiological engagement in Salvokop to address precarious housing and builds on insights from the previous discussion. This alternative theological agenda is firstly discerned in appreciation of the residents stepping out to contribute towards their neighbourhood change. A theological reflection on the vision of Abahlali base Mjondolo, mentioned earlier, offers life lessons of standing for human dignity and resisting injustice in defence of civil rights. Thus, it is expected that both the inner city churches and the residents will face each other around one table of dialogue to determine a collective agenda of reclaiming constitutional rights to a sustainable human settlement. This shift finds its ecclesiological expression White (2013) and his ideas on mission from social margins: 'the margins is not simply a place to send people to, the margins is the place where the church most properly lives, most properly serve the world'. In other words, Davey (2001) correctly states that, it is among marginal people (like those living in Salvokop): ${ }^{6}$

Jesus stimulates faith; he encourages them to comprehend the reality of what makes them marginal. They are receptive not only to the message but also to the invitation to create an alternative way of community life ... (p. 71) 
Davey (2001) continues his reflections focusing on God's instructions as follows:

\begin{abstract}
... the fact that worship takes place in communities of the urban poor is not a secret, of no relevance to the Church outside those places. God's new order is celebrated and claimed among members of the same body who find themselves the undervalorised objects of global economic forces: the unemployed, underpaid and those caught up in debt; migrants seeking security and work; refugees seeking safety and welcome. (p. 106)
\end{abstract}

In alignment with the above reflections, the local churches from Salvokop are operating from the grassroots level among the poor people. This status places them in a position whereby they should learn the real issues of the residents and the neighbourhood in general so that they can be addressed in a real and direct way.

An alternative theological agenda for future ecclesiological engagement in Salvokop secondly recognises a broader partnership with multiple role players from public and private sectors to rally behind a standalone goal of rebuilding the neighbourhood to become a model of justice and reconciliation given its history of injustice. An obstacle to achieve this goal lies in the churches lacking an important aspect of collaboration to promote a shared vision of building a sustainable human settlement. It was astonishing during the World Café and Focus Group meetings to note that some churches do not know each other while operating from the same building blocks. De Beer (2012:256) analyses this weakness stating that in post-apartheid South Africa, the church in many ways has failed to position itself as part of the broader civil society to participate in building society. Elliot (2004:163) responds proposing that churches cannot continue operating privately, instead '... to lay down their logos and their egos to embrace the city together as transformation cannot be achieved through fragmented efforts'. He promotes The Nehemiah Strategy, which encourages the churches to seek cooperation of neighbourhood and civic leaders, spiritual leaders, business leaders, educational institutions, local and state government officials and the media. Through this strategy it is understood that the churches will also be 'a critical companion of strategic and critical processes' (De Beer 2012:256) in the interest of promoting the ideals of justice and human dignity.

Thirdly, other than grassroots leadership and broader partnership, spirituality is a touchstone in discerning an alternative theological agenda for future ecclesiological involvement in the Salvokop neighbourhood. It is argued that in church practices, spirituality matters as Humboldt, Leal and Pimenta (2014) state that it is 'the affirmation of life in a relationship with God, self, community, and the environment that nurtures and celebrates wholeness'. A theological intrinsic flowing from this embodiment shows that it would be underachieving for the churches to engage themselves in Salvokop being unaware that God is the owner of the mission (missio Dei), John 10:10b. In light of this Biblical injunction, the Holy Spirit is the Enabler of the churches to bear witness to a mission that implies human participation in God's work on earth at various multidimensions, which include evangelism, reconciliation, healing, justice and earth keeping, ... (Kritzinger 2011:42-43). Thus, a unique contribution that the inner city churches will make towards promoting quality life in the neighbourhood of Salvokop is shaped by this spirituality, which recognises the role of the residents in problem solving, partnership relationships and networking with public and private sectors.

\section{Executive summary and strategic recommendations}

The main aim of the study has been to describe the problem of precarious housing that the residents of Salvokop neighbourhood are facing and to discern urban ecclesiological role to respond to the situation. Mechanisms surrounding this problem have been explored by means of a critical review of the historical background of Salvokop. Its initial establishment was covered bringing in issues of unfair policies and social exclusion, which affected housing for poor people. The study built on this step to offer a description of the current state of housing problem in Salvokop and how the residents are affected while investigating whether or not there is any involvement of the inner city churches to respond in a more practical way. Leading from these lines, the study concludes that Salvokop does not in one way or the other make exception of other South African urban neighbourhoods suffered from patterns and unjust policies from the colonial and apartheid patronage. It became clear that political ideologies of social exclusions linked to aspect of racial segregation led to dramatic events of fundamental human rights violation. Housing was allocated in accordance with the confinement of unfair laws to favour a certain class of white workers while their black counterparts became subjected to forced removals from Salvokop resulting in poverty and vulnerability. A link between precarious housing, poverty and vulnerability is here acknowledged albeit not developed in these conversations, but the subject may potentially be considered for future project. Thus, lessons learnt from both past and the present social context of Salvokop reveal that the history of unjust policies tends to repeat itself as the neighbourhood remains competitive towards businesses and public offices overlooking an important component of urban social development. In short, the picture of precarious housing as experienced has the following layers:

- gradual degradation of existing housing because of a lack of maintenance and intervention

- social phenomenon of overcrowding in the houses as a result of influx of poor people migrating to the neighbourhood

- insecurity of tenure as the residents remain uncertain of the future of housing in Salvokop

- the rise of shacks and Bagdad informal settlements

- neighbourhood deterioration because of a lack of maintenance and an upgrade of basic infrastructure causing harm to environment. 
A theological agenda for future ecclesiological involvement in Salvokop shows that precarious housing is immense and complex and that the churches involvement requires more than just to run outreach and handout programmes to promote decent housing for poor people. It is expected that the churches working together with the residents will prioritise issues of advocacy and policy lobbying to promote a model of housing, which is socially inclusive to consider all the circumstances of each household residing in the neighbourhood of Salvokop. To plan ahead, issues of immediate attention that need the facilitation from the churches are reflected in the recommendations as follows:

- stakeholders' collaborative and consultative meetings involving community leaders

- building strong partnership relationships with public and private sectors

- land audit and disposal for housing purposes

- establishing a conversation on a range of various housing options to be negotiated and approved with the residents of Salvokop

- upgrading the existing housing stock and basic infrastructures followed by environment upkeep campaigns

- legitimising the current residents determining security of housing tenure

- exploration of home ownership option through rental to buy option for the existing houses

- exploring the Government housing grant to fund the model of affordable housing given the case study of Inkululeko Centre social housing project of $\mathrm{YCH}$.

All in all, the successful integration and execution of these components require wisdom and zealous leadership and commitment of all participants involved to the long-term journey of realising the ultimate goal of the neighbourhood change through housing adapted to circumstances of all the residents. In the same spirit, it is lastly noted that once housing vision is achieved, it will humbly be celebrated as a Christian expression of justice and a contribution to human dignity, bearing in mind that 'mission in the complexity and tangle of the urban will bring us again and again to the cross and resurrection'.

\section{Acknowledgements Competing interests}

The author declares that she has no financial or personal relationships which may have inappropriately influenced her in writing this article.

\section{References}

Artefacts, n.d., viewed 02 April 2017, from http://www.artefacts.co.za/main/ Buildings/bldgframes.php?bldgid $=13201$

Astrup, R., 2005, Pretoria Station Precinct \& Community Development Centre, viewed 16 June 2017, from http://repository.up.ac.za/bitstream/handle/2263/30528/ 01chapter1-part3.pdf?sequence $=4$

Bankston III 2010, Social justice cultural origins of a perspective and a theory, viewed 25 April 2017, from http://www.independent.org/pdf/tir/tir_15_02_01_ bankston.pdf
Bassett, 2013, The role of spatial justice in the regeneration of urban spaces in De Beer (2014). Whose knowledges shape our city? Advancing a community-based urban praxis, viewed 07 May 2017, from http://www.dejure.up.ac.za/index.php/ praxis, viewed 07 May 2017, from http://w
volumes/47-volume-2-2014/articles/de-beer-s

Batho Earth, 2016, Proposed mixed land use township establishment on the remainder of portion 406 of the farm Pretoria Town Lands 351-JR Salvokop, Unpublished report.

Bergman, 2005, Qualitätskriterien transdisziplinärer Forschung. Leitfaden für die evaluation von Forschungsprojekten. Frankfurt am Main, In De Beer 2014, Whose knowledges shape our city? Advancing a community-based urban praxis 47, vol. 2, pp. 218-230.

Constitution of the Republic of South Africa, 1996.

Davey, A., 2001, Urban Christianity and global order: Theological resources for an urban future, SPCK, London.

De Beer, S., 2012, 'Urban South Africa: An opportunity for liberating theological education', Missionalia: South Africa Journal of Missiology 40(3), 251-274.

De Beer, S., 2014a, 'Between life and death': On land, silence and liberation in the capital city, viewed 06 May 2017, from http://www.hts.org.za/index.php/HTS/ article/view/2075/4705debeer2014

De Beer, S., 2014b, Whose knowledges shape our city? Advancing a community-based urban praxis, De Jure 47, 218-230, viewed 20 July 2017.

De Beer, S., 2016, 'Discerning a theological agenda for spatial justice in South Africa: An imperative for sustained reconciliation', HTS Teologiese Studies/Theologica Studies 72(1), 14p. https://doi.org/10.4102/hts.v72i1.3566

De Beer, S., 2017, Discerning a theological agenda for spatial justice in South Africa, Paper presented in a Conference, Pretoria.

Doyle, R. \& Williams, E., 2016, Rural poverty in Wales: Existing research and evidence gaps, viewed 28 July 2017, from http://ppiw.org.uk/files/2016/06/Anintroduction-to-Rural-Poverty.pdf

Elliott, B.J., 2004, Street saints: Renewing America's cities, Templeton Foundation Press, London.

Gaines, D. \& Armstrong, D., 2011, In Goss, N and Smart, N., Play at Play, viewed 16 July 2017, from https://books.google.co.za/books?id=hwwrBwAAQBAJ\&pg=PA81 \&lpg=PA81\&dq=unhousable+film\&source=bl\&ots=1n|Xec29FR \&sig=CiNbjXfNByq 9|4Tzpdduq86hnWo\&hl=en\&sa=X\&ved=0ahUKEwjlOLmVOL_VAhVpJsAKHRX2B7c Q6AEIJjAA\#v=onepage \&q=unhousable $\% 20$ film\&f=false

GAPP/MMA CONSORTIUM, 2003, Salvokop Development Framework - draft development framework, Pretoria, viewed 30 March 2017, from http://repository. up.ac.za/bitstream/handle/2263/30050/02chapter2. pdf?sequence=3\&isAllowed=y

Gloeck, R., 2011, Germinating architecture of growth, viewed 28 April 2017, from http://repository.up.ac.za/bitstream/handle/2263/30050/00front.pdf?sequence=1

Hankela, E., 2014, Ubuntu, migration and ministry: Being human in a Johannesburg Church, Brill, Leiden.

Holland, J. \& Henriot, P., 1986, Social analysis, Linking faith and justice, Orbis, Maryknoll, NY.

Humboldt, S.V., Leal, I. \& Pimenta, F., 2014, 'Does spirituality really matter?: A study on the potential of spirituality for older adult's adjustment to aging', The Japanese Psychological Association Research 56(2), 114-125. viewed 10 July 2017, from http://onlinelibrary.wiley.com/doi/10.1111/jpr.12033/full

Jackson, B., 2005, 'The Conceptual history of social justice', Political Studies Review 3, 356-373, viewed 30 April 2017, from http://www.academia.edu/1588419/The_ Conceptual_History_of_Social_Justice

Korten, D., 1990, Getting to the 21st Century, Kumarian Press, West Hartford, CT.

Kretzmann, J.P. \& McKnight, J.L., 1993, Building communities from the inside out: A path towards finding and mobilizing a community's assets, ACTA Publications, Chicago.

Kritzinger, J.N.J., 2012, 'Overcoming theological voicelessness in the new millennium', Missionalia 40(3), 233-250.

Kritzinger, K., 2011, “"Mission as...” must we choose? A dialogue with Bosch, Bevans \& Schroeder and Schreiter in the South African Context', Mssionalia: Southern Africa Journal of Missiology 39(1/2), 32-59.

Kruythoff, H., 2003, Dutch Urban Restructuring Policy in Action Against Socio-spatia Segregation. Sense or Nonsense, viewed 30 April 2017 from http:// housingamsterdam.net/po_inside/dutchurbanrestructuriing.pdf

Marchant, C., 2004, 'Key Biblical Themes', in M. Eastman \& S. Latham (eds.), Urban Church: A practitioner's resource book, pp. 8-11, SPCK, London.

Massey, D. \& Thrift, N., 2000, City for the many and not for the few, Policy Press, Bristol.

Mbanjwa, X., 2012, 'Schubart Park eviction unlawful - ConCourt', City Press, viewed 29 April 2017, from http://www.news24.com/SouthAfrica/News/ConCourtSchubart-Park-eviction-unlawful-20121009. In de Beer (2014). Between life and Schubart-Park-eviction-unlawful-20121009. In de Beer $(20$

Monte, G.D., 2011, 'Poetry of forgotten wastelands: Transforming a wasteland in Salvokop into a designed enigmatic landscape', dissertation, University of Pretoria, viewed 14 April 2017, from http://hdl.handle.net/2263/25538

Mudzuli, K., 2014, Stats SA to get new R1.4bn headquarters, viewed 06 May 2017, from http://www.iol.co.za/news/south-africa/gauteng/stats-sa-to-get-new-r14bnheadquarters-1704234

Naude, M., 2014, Salvoko Urban Heritage Sensitivity, viewed 30 May 2017, from http://www.sahra.org.za/sahris/heritage-reports/urban-sensitivity-report

Nkosi, N., 2016, 'Forced Club Eviction', Pretoria News, viewed 10 May 2017, from https:// www.pressreader.com/south-africa/pretoria-news/20160720/281479275764475 
Ntakirutimana, E., 2015, 'Facing homeless people in the inner City of Tshwane. A missiological conversation with the Wesleyan Tradition', DTH, University of South Africa, Pretoria.

Pathways out of homelessness, 2015, viewed 15 July 2017, from http://www.up.ac $\mathrm{za} / \mathrm{media} / \mathrm{shared} / 249 /$ ZP_Files/homelessness-report-2015.zp70613.pdf

Pithouse, R., 2009, Abahlali Basemjondolo and the struggle for the city in Durban South Africa, viewed 10 July 2017, from http://abahlali.org/files/Cidades_article.pdf

Pohl \& Hadorn, H., 2006, 'Gestaltungsprinzipien für die transdisziplinäre Forschung', in S. De Beer, 2014, Whose knowledges shape our city? Advancing a communitybased urban praxis 47 volume-2, RSA.

Reimink, T., 2014, Life in a city centre, stuck in decay. Urban risks and vulnerability in the inner city of Pretoria, South Africa, viewed 05 July 2017, from https://dspace. library.uu.nl/bitstream/handle/1874/.../Thesis\%20Tara\%20Reimink.pdf?

SJC, 2017, SAPS and Public Works must divert R100 million, viewed 09 May 2017, from http://www.sjc.org.za/de_lille_s_budget_is_anti_poor

The unpublished Minutes of Salvokop Development Forum, 12 April 2017, Pretoria.

The unpublished Salvokop Development Forum Report 2003.
The unpublished Tenant Booklet Yeast City Housing NPC, Pretoria.

The unpublished 2015 Annual Report, Yeast City Housing, Pretoria.

Thabye, G., 2016, Schubart Park to rise from ashes, viewed 20 July 2017, from https:// www.iol.co.za/news/south-africa/gauteng/schubart-park-to-rise-fromashes-2005804

Tshwane Vision 55, 2013, viewed 11 July 2017, from http://www.tshwane2055.gov. za/images/vision/chapter1_intro_vision2055.pdf

Tunstall, R., Bevan, M., Bradshaw, J., Croucher, K., Duffy, S., Hunter, C. et al., 2013, The link between poverty and housing, viewed 25 April 2017, from https://www.jrf. org.uk/report/links-between-housing-and-poverty

Wenhold, M.W., 2008, 'The sense of space sensation', Masters' thesis, University of Pretoria, SA.

Wesley, J., 1827, The Works of John Wesley (Sermons I-IX), Vol. V. Zondervan Publishing House, Grand- Rapids, Michigan.

White, S.G., 2013, Mission from the margins, viewed 17 July 2017, from https://www. filantropia.fi/news-stories/item/86-mission-from-the-margins 